\title{
Perception of Secondary High School Teacher in Conducting The Classroom-Based Assessment (PBD)
}

\author{
Siti Nurshahirah Misran ${ }^{1}$, Nurul Aini Mohd Ahyan ${ }^{2 *}$, Hanifah Jambari ${ }^{3}$, \\ Nur Hazirah Noh@ $\mathrm{Seth}^{4}$, Mohamad Rasidi Pairan ${ }^{5}$ \\ \{shahirahmisran18@gmail.com ${ }^{1}$,nurul.aini@utm.my²,hanifah-j@utm.my ${ }^{3}$ \} \\ 1,2,3,4,5 School of Education, Faculty of Social Sciences and Humanities, 81300 Skudai, Johor Bahru, \\ Malaysia
}

\begin{abstract}
Classroom-Based Assessment (PBD) is a new assessment system in school to replace the School Based-Assessment (PBS). Referring to past studies on PBS, most of the teachers are facing problems regarding the appropriate way of PBS. Besides, the teachers are also burdened with managing the assessment, especially in terms of time management and lack of equipment and teaching aids in school, leading to difficulties in conducting the assessment. Thus, the purpose of this study is to identify the teachers' perception in conducting the PBD by measuring the teacher readiness, the problems faced by the teachers in terms of time management, the availability of the equipment and teaching aids in school, to help increase the teacher's performance in performing the assessment. The respondents of this study are among 80 secondary school teachers around Skudai, Johor. The descriptive data were analysed using the Statistical Package for Social Sciences (SPSS) involving frequency, mean score and percentage value. The result shows that the teacher's readiness is at a very high level, so as the problems related to time management. On the other hand, the availability of equipment and teaching aid in school is at a moderate level since the facilities are not supplied by the school, and the teachers need to prepare it themselves.
\end{abstract}

Keywords: Classroom-Based Assessment, Teachers` Perception

\section{Introduction}

Over decades, Malaysian assessment system only focuses on written assessments. Since 2012, a transformation was made by the Ministry of Education on a valuation system known as School-Based Assessment (PBS). Through this system, the students' performance is measured holistically and comprehensively in terms of academic, co-curricular, sports and psychological developments of students, without disregarding the written examination. According to [1], the school may build, maintain and evaluate the students through the implementation of PBS, to create an action plan to address the weaknesses arose.

Throughout the PBS implementation, there are many challenges faced by the teachers. Teachers who are not skilled but willing to conduct the assessment contribute to the failure of its implementation. Peng [2] stated that, each teacher needs to have enough training, knowledge, and skills to deliver an efficient teaching and learning session. Similarly goes to when conducting the assessment. Teachers should be given adequate training and knowledge of the assessment system before being conducted. Insufficient knowledge can impair the effectiveness of assessments made on students. In addition, the implementation of PBS was temporarily suspended to examine the teacher's burden until the matter was resolved. The diversity of teachers' commitment to school and complex assessment systems are the contributing factors to the difficulties faced by teachers. The assessments that need to be performed throughout the entire year was incomplete due to the heavy workload to be 
completed on time. Faulty materials and equipment in schools for teaching and learning (T\&L) purposes create barriers for teachers to implement projects as required by PBS. As highlighted by Mohamed Noh et al. [3], the successful implementation of a program can be helped by using the teaching aids available to be used by the teachers. Besides, the availability of teaching equipment facilitates the teaching and assessment process, indirectly impacts the students' retention because the students can explain what they have learned during T\&L process.

Given too many arguments regarding PBS in terms of time management, abundant of assessment documents, and high possibilities of incomplete syllabus, a new assessment system was introduced called the Classroom-Based Assessment (PBD) in early 2019. PBD was designed in 2018 to improve the PBS system that burdens teachers' duties. PBD is a continuous assessment of teaching and learning sessions to obtain information on student progress, efficiency, and achievement.

Thus, the purpose of this study is to identify the teachers' perception towards the implementation of PBD, where the difficulties by implementing PBS were used as references to the study. Three objectives were outlined which are to measure the level of teacher readiness in conducting PBD, to identify the problems faced by teachers in terms of time management and the availability of equipment and teaching aids at school in conducting PBD.

\section{Methodology}

This study was conducted using quantitative research design by using a survey. A set of questionnaire was developed as an instrument to obtain feedback regarding teachers' perception in conducting PBD. A group of secondary school teachers from Skudai, Johor Bahru were selected randomly as the respondents by getting their feedback on the distributed questionnaires. The teachers are from SMK Taman Universiti 1, SMK Taman Universiti 2, SMK Taman Desa Skudai and SMK Taman Selesa Jaya 2.

Figure 1 shows the research design of this study. The research instrument is developed based on three factors; the teacher readiness, time constraints and factors of T\&L facilities. From the teacher readiness factor, the level of teacher acceptance in implementing PBD was measured, mentally and physically. Time constraint factor was related to the limitation of time management at school. The researcher identified the possibilities of teachers facing time constraints while implementing the PBD in terms of instrument preparation, evidence, and data filling. Besides, the study also involved the time allocation of teachers to manage their time for school administration jobs, as well as a scheduled teaching session. By right, teachers need to ensure that the students understand the previous lesson before they proceed to next chapter. Thirdly, the availability factor of teaching and learning facilities in the school was conducted to study the impact of its implementation towards PBD assessment. 


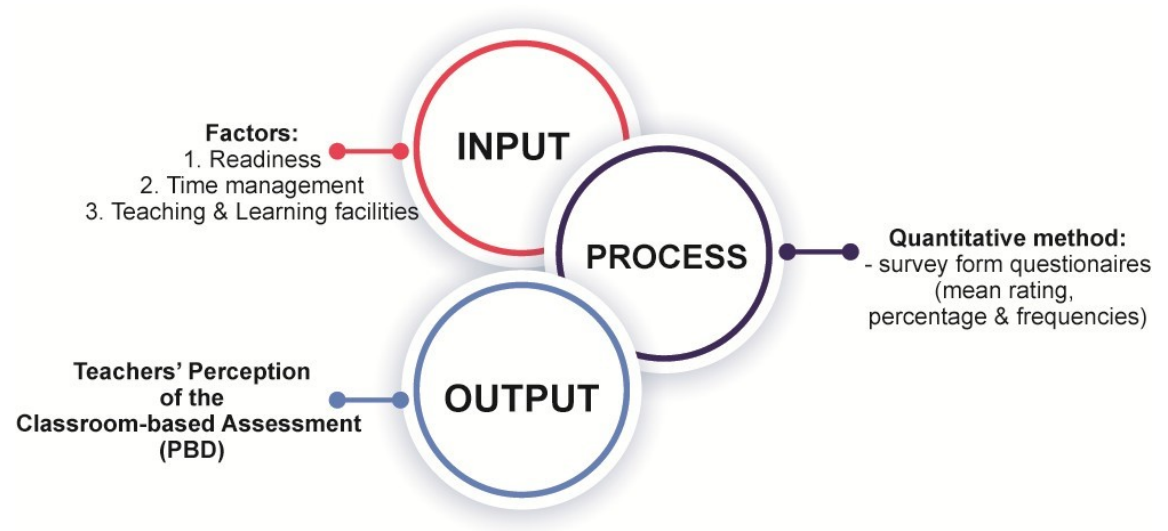

Fig. 1. The research design

\section{Result and Discussions}

This study was conducted on 80 respondents among secondary's school teachers. Figure 2 shows the result of the respondent based on the demography data. The number of female respondents, which is 60 female respondents, is higher than men. Among the races, the highest number of respondents is Malay with 63 respondents, followed by 10 Chinese respondents and 7 Indians respondents. Also, 17 respondents are in the age between 36-40 years old, followed by 31-35 years old with 19 respondents, and 20 respondents in between 25-30 years old. The highest group of respondents is 24 , with the age of 40 and above. On average, the highest qualification among the teachers is a bachelor's degree with 75 respondents, while the remaining five respondents have master's degree as their highest qualification.

Meanwhile, based on their teaching experience, 33 respondents have more than ten years of experience. The second highest is between 6-10 years teaching with a total of 25 respondents. The lowest number of respondents is 9 , who had less than two years of teaching experience, and the second last was between 2-5 years' experience with 13 respondents. For the PBS experience, the majority of respondents already have two years of teaching experience as illustrated in the figure below, where 67 respondents have two years' experience conducting PBS compared to 13 respondents who have only one year experience.

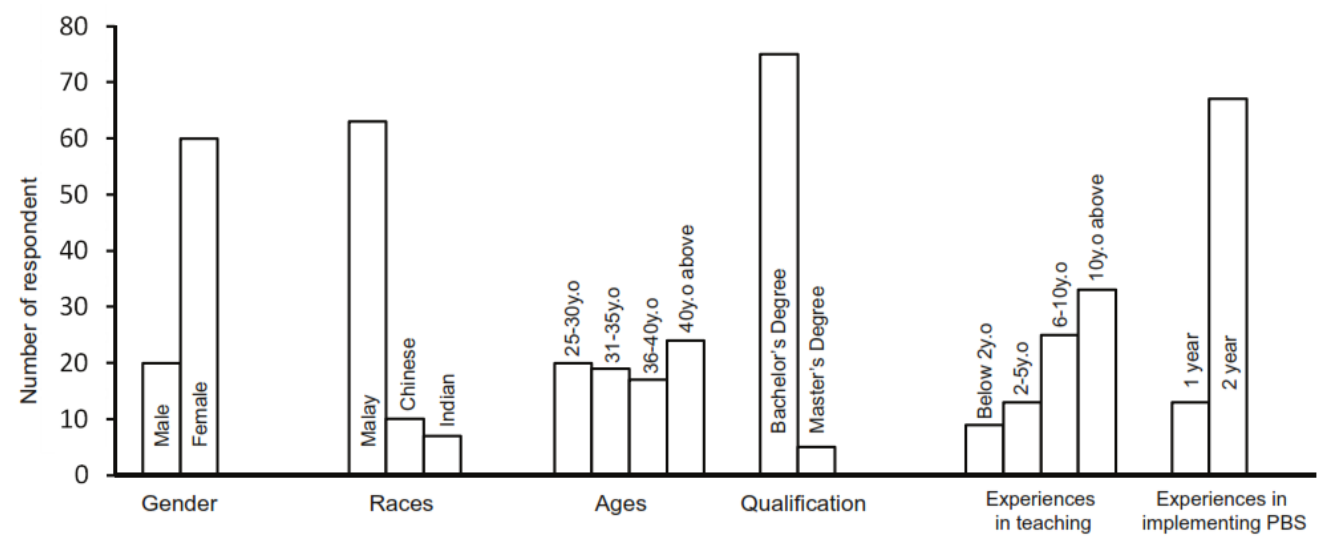

Fig. 2. The results of the respondent based on demography 
Based on Table 1, the results show that most respondents have a high perception of the willingness to implement PBD, proven through the result of the questionnaire analysis which shows the mean scales for all items related to the level of readiness is 4.10 . Only a handful of respondents showed less willingness but did not give an impression on the mean value. Through the findings of the question item analysis, there are points which indicate that teachers are well-prepared to implement the PBD. This can be seen through question items, where teachers are prepared to evaluate student performance according to performance standards. A total of 75 respondents $(93.75 \%)$ agree with this statement. Next, teachers are ready to respond to students according to performance standards. A total of 75 respondents $(93.75 \%)$ agreed with this statement. The highest mean value reflects the level of readiness of the teacher. It shows that the teacher already knows the technique of using the PBD reporting template to record student achievement. It is undeniable that all teachers need to be prepared with all the fundamental changes made in improving the education system in our country. This change occurs due to economic, climate and technological developments. Official documents have been developed as a guide for teachers to conduct the assessment.

Norsyuhadah [4] mentioned that through the assessment, teachers could evaluate the level of performance of each student. With this assessment, teachers can also improve the teaching process and contribute to the effectiveness of the assessment [5]. Hence, the readiness of teachers and understanding in standard documents will facilitate teachers in assessing and responding to students according to the established knowledge level. Similarly, the teacher's knowledge in recording the data using the template has been provided. According to [6], readiness is about willingness. With the willingness shown by the teacher, it can be seen that all teachers are ready to implement the PBD.

Table 1. The average mean for each research objectives

\begin{tabular}{|c|l|c|c|}
\hline \multirow{2}{*}{ No } & \multicolumn{1}{|c|}{ Objective } & Mean & AverageRate \\
\cline { 3 - 4 } & \multicolumn{1}{|c|}{$\begin{array}{c}\text { To identify the level of teacher readiness in } \\
\text { conducting PBD assessment }\end{array}$} & 4.02 & Very High \\
\hline 2 & $\begin{array}{l}\text { To identify the problems faced by teachers } \\
\text { during the implementation of PBD } \\
\text { assessment in terms of time management }\end{array}$ & 3.69 & High \\
\hline 3 & $\begin{array}{l}\text { To identify the availability of equipment } \\
\text { and teaching aids at school in conducting a } \\
\text { PBD assessment }\end{array}$ & 3.59 & Medium \\
\hline
\end{tabular}

For the second objective, the problem faced by teachers in terms of time management was identified. The mean value recorded is 3.69. There were three main problems identified by the researcher. The main challenge of the teacher in conducting the assessment is the requirement of more extended time allocation to assess lower-class students than upper classes. According to [7], every student needs more personal attention and always need to socialise. Moreover, for weak students, most of them need more concentration than their peers. This has become an issue for teachers due to the objective of the assessment is not just focusing on just one topic, but are according to the subject content standard as a whole. Secondly, each session of $T \& L$ requires teacher to measure an instrument which is appropriate and coincide with the content standard, to achieve teaching objectives. There are various methods that teachers can use such as through role-play, easy quiz, storytelling, simulation and many more. As according to [8], every teacher who teaches, should have the teaching and assessment methods that make it easier for students to achieve it. Hence, an instrument which 
is used as teaching materials must be able to increase the students understanding, as well as it must be tailored to the teaching purposes. Thirdly, it is a matter of teachers management time which were frequently involved with outdoors tasks such as meetings, workshops and courses which causes them to take a leave. This might affects teachers to record student achievement assessment data. This situation is inevitable as teachers are often charged with endless work and other tasks besides the main task taken from the Ministry of Education [9]. This is undoubtedly a question of teachers' duty as well as teaching and demands for continuous assessment.

The highest mean value is recorded through the item of 'the teacher uses the internet to find the assessment material and to surf the data in the school'. The absence of internet networking in schools requires teachers to provide their initiatives to ensure the success of the assessment and record data in the official portal. According to [10], the school equipment used by teachers and students is to help deliver lessons in the classroom. Thus, the absence of a widespread internet network in schools contributes to the creativity of teachers in making assessments and doing online work. Furthermore, the high mean of $3.89 \%$ is related to the school providing LCD facilities, but the number is limited. Assessment can also be done through the use of LCDs such as online quizzes that are more exciting to the students or through video or picture rendering. Khaled [11] said the use of teaching aid in teaching sessions was considered the best way to practice teaching. Meanwhile, Mohd Azidan [12] stated that teaching aids are essential as it serves to instigate students' interests, develop understanding and thinking, maintain teaching, strengthen and reinforce memory, provide students with the ability to understand, mobilize student activities and activities, large-scale, varying teaching and familiarizing students with current information tools. Furthermore, according to a study conducted by Norhayati [13], students' reminder rates indicate that if the teacher performs listening activities, $80 \%$ of pupils tend to pay attention rather than just by seeing and mentioning activities (conventional T\&L approach). The next item is for teachers to prepare their materials such as pictorial materials to diversify their assessment activities. Faizah [14] stated that the role of teachers is essential to create creativity in the classroom.

\section{Conclusion}

In conclusion, this study proves that teachers are more confident with the implementation of PBD than PBS. This is clear and proven through the analysis that the respondents have answered. Besides, some issues and availability of school equipment have also been identified. Hopefully, through this study, it may help teachers to solve this problem and conduct the assessment process in school. Overall, it can be concluded that teachers' perceptions of the implementation of PBD are at high levels. Almost all teachers are ready to implement the PBD, problems related to time management have also been identified, and teachers' availability of equipment and teaching aids in schools has also been discussed.

\section{References}

[1] Dalail, R., Fook, C.Y., Sidhu, G.K.: Reorientation of Knowledge Among Primary School Teachers in Adopting a Transformed Classroom Assessment Policy. In: Fook C., Sidhu G., Narasuman S., Fong L., Abdul Rahman S. (eds) 7th International Conference on University Learning and Teaching (InCULT 2014) Proceedings. Springer, Singapore (2016)

[2] Peng, Y.K.: Level of Achievement and Implementation of Science Process Skills In the Trainer Circle. Masters Thesis. Universiti Sains Malaysia (2007) 
[3] Mohamed Noh, N., Ahmad Mustafa, H.M., Hamzah, M., Ismail, M.A. \& Abdullah, N.: Use of Technology Innovation in Teaching: Teacher Challenges in E-Learning. Proceedings Of The 7th International Malaysian Educational Technology Cinvention (IMETC 2013) (2013).

[4] Norsyuhadah, M.: Implementation of school-based assessment (PBS) for Science Subjects in Sekolah Kebangsaan Daerah Pontian, Johor. Masters Thesis, Universiti Tun Hussein Onn Malaysia (2013)

[5] Mohd Hamzah, M. I. \& Hussin, S.: Strategic Change Management In School Establishment (Policy Implementation Process). Universiti Malaya: Kuala Lumpur (2009)

[6] Mohd. Izham, M.H. \& Noraini, A.: Levels of Science Teacher Preparedness in the Use of ComputerBased Information Technology in the Teaching and Learning Process. Vol. 46 (June 2007) pp. 4560. Jurnal Teknologi (2007)

[7] Pang, V.: Preparation of Knowledge and Skills of the 21st Century Teaching and Learning. Style Campus Teacher Education Institute (PIPK), Gaya, Sabah, Malaysia (2005)

[8] Mohamed Nor, A.A., Nur Amiera, A., Ramlee, M., Balamuralithara, B. \& Nor Kalsum, M.I.: Use of Instructional Teaching Topics for Work Topics Wood, Plumbing and Metal. Vol. 3:1 (2014) pp. 77-85. Sains Humanika (2014)

[9] Ministry of Education Malaysia (KPM): https://www.moe.gov.my/. Retrieved at 6 March 2019 (2013)

[10] Zakiul, H. M., Syarafina, S. \& Nurr Hidayah, A.S.: Effective Effects Of Bacadol Learning Teaching (Abm) In Amali Electrical Motors In Best Community College Collection. National Innovation and Invention Competition Through Exhibition (iCompEx'18) (2018)

[11] Khaled, A.B.O.: An-Nur: Teaching Arabic to students who speak a Malay. Universiti Malaya: Kuala Lumpur (2003)

[12] Mohd Azidan, A.J.: Use of teaching aids in teaching Arabic. Faculty of Languages and Linguistics, University of Malaya (1998)

[13] Norhayati, C.H.: The Effectiveness of Animation in Arabic Language Learning. Masters Thesis, Universiti Malaya (2011)

[14] Faizah, J.: Teaching aids in Teaching and Learning in Sekolah Menengah Kebangsaan (SMK) Daerah Pontian. Masters Thesis. Universiti Tun Hussein Onn, Malaysia (2017) 